\title{
Endogenous LPS Alters Liver GH/IGF System Gene Expression and Plasma Lipoprotein Lipase in Goats
}

\author{
Z. L. XIE ${ }^{1}$, P. S. YE ${ }^{1}$, S. K. ZHANG ${ }^{1}$, Y. S. ZHANG ${ }^{1}$, X. Z. SHEN ${ }^{1}$ \\ ${ }^{1}$ Key Laboratory of Animal Physiology and Biochemistry, College of Veterinary Medicine, Nanjing \\ Agricultural University, Nanjing, China
}

Received June 17, 2014

Accepted December 12, 2014

On-line March 24, 2015

\begin{abstract}
Summary
Endotoxin lipopolysaccharide (LPS) affects the ruminant health and animal performance. The main purposes of this study were to investigate the potential effects of GH/IGF system and lipoprotein lipase (LPL) concentration on resistance the circulating LPS concentration increased in liver with high concentrate diet treatment. Non-lactating goats were randomly allocated to two groups: a high-concentrate diet (HCD) or a lowconcentrate diet (LCD) in cross over design and the blood collection at different time points after feeding at the end of the experiment. The average rumen $\mathrm{pH}$ was significantly reduced $(\mathrm{P}<0.05)$, but the duration with $\mathrm{pH}$ was not more than $120 \mathrm{~min}$ in the HCD group. The plasma LPL concentration was significantly raised $(P<0.05)$. However, from $2 \mathrm{~h}$ onwards, LPS concentration was significantly reduced $(P<0.01)$ in the HCD group compared with LCD group. In addition, the plasma IGF1 concentration and the hepatic insulin-like growth factor-1 receptor (IGF1R) mRNA expression were markedly reduced $(\mathrm{P}<0.05)$. However, growth hormone $(\mathrm{GH})$ secretion at 15,30 , and 45 min after feeding and growth hormone receptor (GHR) mRNA expression in the liver was significantly increased $(P<0.05)$ in $H C D$ group. The correlation analysis showed that the plasma LPL concentration was positively correlated with hepatic GHR mRNA expression $(P<0.05)$. Conversely, the plasma LPS concentration was negatively correlated with $\mathrm{LPL}$ concentration $(\mathrm{P}<0.05)$. These findings reveal that alterations in GH/IGF system function in response to a high-concentrate diet are accompanied by corresponding changes in systemic LPL in non-lactating goats' liver in presence of endogenous LPS stress.
\end{abstract}

\section{Key words}

Endotoxin lipopolysaccharide • GH/IGF system • Lipoprotein lipase

\section{Corresponding author}

Y. S. Zhang, Key Laboratory of Animal Physiology and Biochemistry, College of Veterinary Medicine, Nanjing Agricultural University, Nanjing 210095, China. Fax: +86 2584398669. E-mail: zhangyuanshu@sina.com.cn

\section{Introduction}

Current feeding practices for ruminants use highly fermentable diets to maximize energy intake to change the environment in the rumen and decrease the ruminal $\mathrm{pH}$ or cause ruminal acidosis (Krause and Oetzel 2006), with a loss of animal performance (Stone 2004). One consequence of such feeding is to increase the rate of endotoxin lipopolysaccharide (LPS) (Emmanuel et al. 2008, Khafipour et al. 2009). High concentrate diets can cause a 20-fold increase in LPS release within rumen (Andersen et al. 1994a). The phenomenon of high concentrate diet induced LPS production was defined as endogenous LPS and result in the stress (LPS stress), which caused rumen papillae damage (Steele et al. 2009). Moreover, papillae damage allows entry of LPS into the blood and leads to generalized effects (Andersen et al. 1994a). However, the blood LPS is cleared from the portal circulation by the liver (Andersen et al. 1994b, Harris et al. 2002), a process that involves macrophages (Kupffer cells) or neutralization by lipoproteins (Kasravi et al. 2003a). Thus, the liver plays a central role in clearing toxins trans-located into blood from inflammatory sites (Waldron et al. 2003).

In ruminants alterations in the growth hormone (GH)-insulin-like growth factor (IGF) system occur in response to nutritional stress (Lee et al. 1997, McGuire et 
al. 1992). Alteration of dietary nutrition could mark effects on plasma $\mathrm{GH}$ and insulin like growth factor 1 (IGF1) concentration and mRNA abundance within GH/IGF system in sheep (Hua et al. 1995, O'Sullivan et al. 2002), heifers (Nosbush et al. 1996), beef steers (Thorp et al. 2000), bulls (Renaville et al. 2000) and calves (Smith et al. 2002). Importantly, activated GH/IGF activity are associated with lipoprotein enhancement and considered the main factors affecting IGF1 status in mammals with the nutrition alteration (Goldstein and Phillips 1991, Lee et al. 1997). Nutritional deficiency, induced by food deprivation or restriction, suppresses the hepatic gene expression of GHR (Dauncey et al. 1994, Pell et al. 1993, Sohlstrom et al. 1998, Straus and Takemoto 1990, Weller et al. 1994). Previous results showed to impair GH/IGF activity could decrease the plasma high density lipoprotein and low density lipoprotein concentration (Sherlock and Toogood 2007). Additionally, the lipoprotein lipase (LPL) enhances the affinity with lipoprotein to binding LPS and transfers into hepatocytes detoxification (Kasravi et al. 2003b). However, little is known about how mediates or interaction the LPS detoxification in the liver with the nutrition alteration in ruminant.

The objective of this study was to test the hypothesis that changing the level of feed concentrates in the diet leads to alterations in the plasma LPS concentration that are accompanied by corresponding changes in plasma LPL and hepatic mRNA expression within GH/IGF system as a way to resist endogenous LPS stress, in order to resume production performance.

\section{Materials and Methods}

\section{Experimental design and goat management}

Twelve 2-year old non-pregnant, non-lactating female Saanen goats were housed and treated in accordance with the guidelines established by the People's Republic of China regarding animal welfare. All procedures were pre-approved by the Institutional Animal Care and Use Committee of Nanjing Agricultural University. Before the experiments, the goats were dewormed with oral Albendazole (15 mg/kg body weight) and subcutaneous Ivermectin $(0.2 \mathrm{mg} / \mathrm{kg}$ body weight), and were acclimated to individual pens $(120 \times 100 \mathrm{~cm})$. All goats were installed with rumen fistulae and kept under uniform management condition for adaptation to the new environment during one week. The goats were randomly allocated to two groups: a high- concentrate diet (HCD, $\mathrm{n}=12$ ) group and a lowconcentrate diet (LCD, $\mathrm{n}=12$ ) group in a cross over design. Diets were formulated to meet or exceed the minimum nutrient requirements as recommended by NRC (2001) using the Cornell-Penn-Miner System (Table 1). The goats were fed twice daily at 0800 and 2000. Water was freeing available. The each feeding period lasted 42 days.

Table 1. Ingredient and nutrient composition of highconcentrate diet (HCD) and low-concentrate diet (LCD).

\begin{tabular}{|c|c|c|}
\hline Item & HCD & LCD \\
\hline \multicolumn{3}{|l|}{ Ingredients } \\
\hline Hay & 32.00 & 48.00 \\
\hline Purple medic & 8.00 & 12.00 \\
\hline Corn & 43.75 & 28.78 \\
\hline Soybean meal & 12.68 & 8.45 \\
\hline Limestone & 1.15 & 0.77 \\
\hline $\begin{array}{l}\text { Calcium hydrogen } \\
\text { phosphate }\end{array}$ & 1.65 & 1.10 \\
\hline Salt & 0.60 & 0.40 \\
\hline Premix ${ }^{l}$ & 0.75 & 0.50 \\
\hline \multicolumn{3}{|l|}{ Nutrients composition } \\
\hline $\begin{array}{l}\text { Net energy } \\
(M J / k g)\end{array}$ & 5.89 & 5.40 \\
\hline Crude protein (\%) & 13.75 & 12.24 \\
\hline $\begin{array}{l}\text { Neutral detergent } \\
\text { fiber }(\%)\end{array}$ & 27.69 & 36.55 \\
\hline $\begin{array}{l}\text { Acid detergent } \\
\text { fiber }(\%)\end{array}$ & 17.54 & 24.04 \\
\hline Calcium (\%) & 1.05 & 0.87 \\
\hline Phosphorus (\%) & 0.51 & 0.40 \\
\hline
\end{tabular}

${ }^{1}$ Provided per kg of premix: Vitamin A, $6000 \mathrm{U}$; Vitamin D2, $500 \mathrm{U}$; Vitamin $\mathrm{E}, 80 \mathrm{mg} ; \mathrm{Cu}, 6.25 \mathrm{mg} ; \mathrm{Fe}, 62.5 \mathrm{mg} ; \mathrm{Zn}$, $62.5 \mathrm{mg}$; Mn, $50 \mathrm{mg}$; I, $0.125 \mathrm{mg}$; Co, $0.125 \mathrm{mg} ;$ Mo, $0.125 \mathrm{mg}$

\section{Sample collection and analysis}

\section{Sample collection}

On day-42 of each diet period, 16 blood samples collected by jugular vein puncture into heparinized vacutainers at $15 \mathrm{~min}$ intervals for $4 \mathrm{~h}$ from 0800 after 42 days on each period for measuring growth hormone. The samples were immediately placed on ice and within $20 \mathrm{~min}$ of collection, centrifuged at $3000 \times \mathrm{g}$ at $4{ }^{\circ} \mathrm{C}$ for $10 \mathrm{~min}$ and stored at $-20{ }^{\circ} \mathrm{C}$ until analysis. The same time sample of rumen fluid was collected by filtration through 
a cotton cloth at 15 min intervals for $4 \mathrm{~h}$ from 0800 after 42 days on each period. After measured the $\mathrm{pH}$ value for each sampling point, the sample was stored at $-20{ }^{\circ} \mathrm{C}$ until analysis. The liver was collected by biopsy in the first period. At the end of the experiment, the goats were slaughtered by captive bolt followed by exsanguinations in the second period feeding. Liver tissue was collected washed twice with cold physiological saline $(0.9 \% \mathrm{NaCl}$ solution) to remove blood and other possible contaminants, and then transferred into liquid $\mathrm{N}$ and stored at $-80{ }^{\circ} \mathrm{C}$ until analysis. The slaughter and sampling procedures complied with the "Guidelines on Ethical Treatment of Experimental Animals" (2006) No. 398 set by the Ministry of Science and Technology, China and the "Regulation regarding the Management and Treatment of Experimental Animals" (2008) No. 45 set by the Jiangsu Provincial People's Government.

Measured plasma IGF1, LPL, LPS and GH concentration

The IGFI, LPL and LPS concentration of plasma (sampling point at $0 \mathrm{~h}, 2 \mathrm{~h}$, and $4 \mathrm{~h}$ ) was measured. The IGF1 concentration measured using a competitive ${ }^{125}$ I-RIA kit with an anti-IGF1 raised in rabbits and an anti-rabbit precipitant (goat). The kit purchased from Beijing North Institute of Biological Technology (Beijing, China). Briefly, IGF1 separated from binding proteins by acid/ethanol $(12.5 \%$ of $2 \mathrm{~mol} / \mathrm{l} \mathrm{HCl}$ and $87.5 \%$ ethanol) precipitation and each sample was analyzed in duplicate. Diluted plasma concentrations paralleled the standard curve indicating that the plasma IGF1 and IGF1 of standards were immunologically similar. The intra-assay (precision) and inter-assay CV (reproducibility) were 2 and $4.5 \%$, respectively.

Plasma LPL concentration was determined using the Total Lipoprotein Lipase Detection Kit, purchased from Jiancheng Biotechnology Institution (Nanjing, China). Plasma LPS concentration was measured using the Goat-LPS Elisa Assay Kit according to the manufacturer's instructions after diluting the samples 1:3 with pyrogen-free water and. The kit was purchased from Shanghai Lengton Bioscience Co. (Shanghai, China). Plasma LPS results was used a 96-well micro-plate with absorbance read at $450 \mathrm{~nm}$ on a micro-plate reader (RT6000, RayTo).

Measured the GH concentration using 16 blood samples through a competitive ${ }^{125}$ I-RIA kit with an anti$\mathrm{GH}$ raised in rabbits and an anti-rabbit precipitant (donkey), purchased from Beijing North Institute of Biological Technology (Beijing, China). Each sample was analyzed in duplicate. Diluted plasma concentrations paralleled the standard curve indicating that the plasma $\mathrm{GH}$ and $\mathrm{GH}$ of standards were immunologically similar. The parallelism was described previously (Hashizume et al. 2005). The intra-assay (precision) and inter-assay CV (reproducibility) were 4.8 and $6.1 \%$, respectively.

\section{Assessment of GH receptor and IGF1 receptor}

$m R N A$

The methods for total RNA extraction and RNase protection were as described elsewhere (Katsumata et al. 2000). 0.5 g liver tissue was used TRIZOL (Invitrogen, Beijing, China) to isolate total RNA which quantified by measuring absorbance at $260 \mathrm{~nm}$ in a NanoDrop ND-1000 Spectrophotometer (Desjardins and Conklin 2011). cDNA was generated from $2 \mu \mathrm{g}$ of total RNA from each of the tester populations, and was converted by M-MLV reverse transcriptase (Promega, USA) as indicated by the manufacturer (protocol: heated to $95^{\circ} \mathrm{C}$ for $2 \mathrm{~min}$, kept for 5 min at $70^{\circ} \mathrm{C}$ and then chilled on ice. cDNA was generated for $1 \mathrm{~h}$ at $37^{\circ} \mathrm{C}$ ).

Real-time PCR was performed using a SYBR Green PCR Master Mix (Roche, Germany) in a Bio-Rad $\mathrm{MyiQ}^{\mathrm{TM}}$ Detection System (Applied Biosystems), according to the manufacturer's instructions. The abundances of GHR and IGF1R mRNA were determined. The relative amount of mRNA for each target gene was determined from the ratio against the mRNA of $\beta$-actin. The thermal cycling conditions were $2 \mathrm{~min}$ at $50^{\circ} \mathrm{C}$, and $10 \mathrm{~min}$ at $95^{\circ} \mathrm{C}$, followed by 40 repeats at $95^{\circ} \mathrm{C}$ for $20 \mathrm{~s}$,

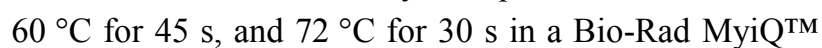
Detection System (Applied Biosystems, USA). According to the comparative threshold cycle $(\mathrm{Ct})$ method, the amount of target mRNA normalized to $\beta$ actin and relative to an internal control was calculated by $2^{-\Delta \Delta \mathrm{Ct}}$. The GH receptor (GHR) primers (Invitrogen, Shanghai, China) was forward (5'-TCCAGCCTCTGT TTCA-3') and reversed (5'-CCACTGCCAAGGTCAA3'), IGF1 receptor (IGF1R) primers was forward (5'GCTCACCCAGGGAACTACAC-3') and reversed (5'CCACTATCAACAGAACCGCAAT-3'), and $\beta$-actin primer was forward (5'-CGGGATCCATCCTGCGTC TGGACCTG-3') and reversed (5'-GGAATTCGGAAG GAAGGCTGGAAGAG-3'). 
Table 2. Effects of two experimental diets on ruminal pH, plasma LPL and IGF1 concentration in non-lactating Saanen goats.

\begin{tabular}{|c|c|c|c|c|c|c|c|}
\hline \multirow{2}{*}{ Item } & \multirow{2}{*}{ LCD } & \multirow{2}{*}{ HCD } & \multirow{2}{*}{ SEM } & \multicolumn{4}{|c|}{$P$-value } \\
\hline & & & & Group & Diets & Times & Group $\times$ Times $\times$ Diets \\
\hline Average ruminal $p H$ & $6.47^{\mathrm{a}}$ & $6.05^{b}$ & 0.063 & 0.015 & 0.021 & 0.067 & 0.048 \\
\hline $\begin{array}{l}\text { Total time }<p H 6.0 \\
(\mathrm{~min} / 4 \mathrm{~h})\end{array}$ & 87.0 & 118.9 & 19.38 & 0.27 & 0.42 & 0.94 & 0.76 \\
\hline $\begin{array}{l}\text { Time at }<\text { pH } 5.8 \\
(\min / 4 \mathrm{~h})\end{array}$ & $27.3^{\mathrm{a}}$ & $53.4^{\mathrm{b}}$ & 9.09 & 0.035 & 0.046 & 0.87 & 0.57 \\
\hline $\begin{array}{l}\text { Plasma LPL } \\
\text { (U/mg prot) }\end{array}$ & $2.03^{\mathrm{a}}$ & $3.903^{b}$ & 0.067 & $<0.01$ & $<0.01$ & $<0.01$ & $<0.01$ \\
\hline $\begin{array}{l}\text { Plasma IGF1 } \\
(\mathrm{ng} / \mathrm{ml})\end{array}$ & $7.564^{\mathrm{a}}$ & $4.900^{\mathrm{b}}$ & 0.127 & 0.007 & 0.003 & 0.013 & 0.009 \\
\hline
\end{tabular}

${ }^{a}, b$ Means within the same row followed by different superscript letters differ significantly $(P<0.05)$. Values are mean $\pm S E M$, $n=12 /$ group.

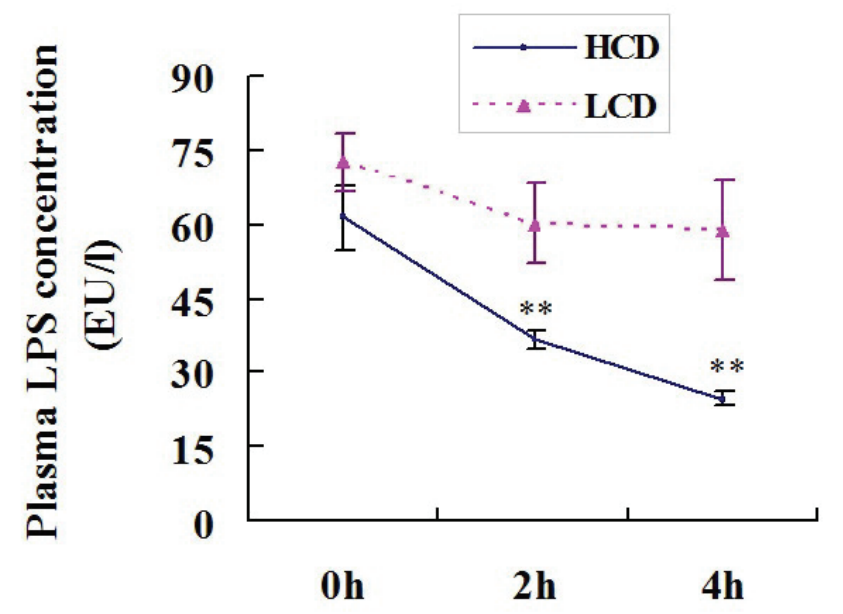

Sampling times

Fig. 1. LPS concentrations in non-lactating Saanen goats fed a high concentrate diet (HCD) or low concentrate diet (LCD). Values are means $\pm S E M, n=12 /$ group. ** indicates significant difference between $\mathrm{HCD}$ and $\mathrm{LCD}, \mathrm{P}<0.01$.

\section{Statistical analysis}

Data are expressed as means \pm SEM. Data for parameters of the IGF system in blood and liver tissue and differences in rumen $\mathrm{pH}$ content were analyzed by ANOVA. Differences with $\mathrm{P}<0.05$ were considered to be significant.

\section{Results}

\section{Rumen $\mathrm{pH}$}

The rumen $\mathrm{pH}$ was lower (6.47 and 6.05) between the LCD group and HCD group $(\mathrm{P}<0.05$,
Table 2). There was no difference in the duration of rumen $\mathrm{pH}$ below 6.0 , but has an obvious increased at the time $\mathrm{pH}$ below $5.8(\mathrm{P}<0.05)$. Overall, for both diet the duration with ruminal $\mathrm{pH}$ below 5.8 was less than the $180 \mathrm{~min}$ considered threshold on the post-feeding for subacute ruminal acidosis (SARA).

\section{Plasma LPS concentration}

Plasma LPS concentration was lower $(\mathrm{P}<0.05)$ in the HCD than that in the LCD group (Fig. 1). No change in LPS concentration at $0 \mathrm{~h}$ was observed following treatment with the different diets $(\mathrm{P}>0.05)$ (Fig. 1). In the LCD group, plasma LPS concentration decreased from 74.4 $\pm 5.7 \mathrm{EU} / 1$ at $0 \mathrm{~h}$ to $59.9 \pm 8.1 \mathrm{EU} / 1(\mathrm{P}<0.01)$ at $2 \mathrm{~h}$ after feeding and consecutively remained lower $(\mathrm{P}<0.01)$. In the HCD group, plasma LPS concentrations decreased from $2 \mathrm{~h}$ onwards, and were lower $(\mathrm{P}<0.01)$ than those in the LCD group.

\section{Plasma LPL, IGF1 and GH concentration}

Marked differences in the plasma indices of LPL and IGF1 were observed between the two feeding groups (Table 2). The HCD treatment induced an increase in LPL concentration $(\mathrm{P}<0.05)$ compared to the LCD group, but the plasma IGF1 concentration was lower $(\mathrm{P}<0.05$, Table 2). Plasma GH secretion responses to a HCD supplementation in non-lactation Saanen goats are shown in Figure 2. The mean plasma GH concentrations in the LCD control goats varied within the range of 2.0 to $4.1 \mathrm{ng} / \mathrm{ml}$, and the LCD supplementation did not alter basal GH concentrations significantly during the postfeeding $4 \mathrm{~h}$. The HCD supplementation significantly 
stimulated $\mathrm{GH}$ release $(\mathrm{P}<0.05)$. The average $\mathrm{GH}$ levels in goats began to rise just at the post-feeding, and were significantly increased at $15 \mathrm{~min}(8.9 \pm 1.1 \mathrm{ng} / \mathrm{ml}), 30 \mathrm{~min}$
$(7.4 \pm 0.9 \mathrm{ng} / \mathrm{ml})$ and $45 \mathrm{~min}(5.1 \pm 0.6 \mathrm{ng} / \mathrm{ml})$ after the feeding in the HCD group compared with the respective sampling time in the LCD group $(\mathrm{P}<0.05)$.

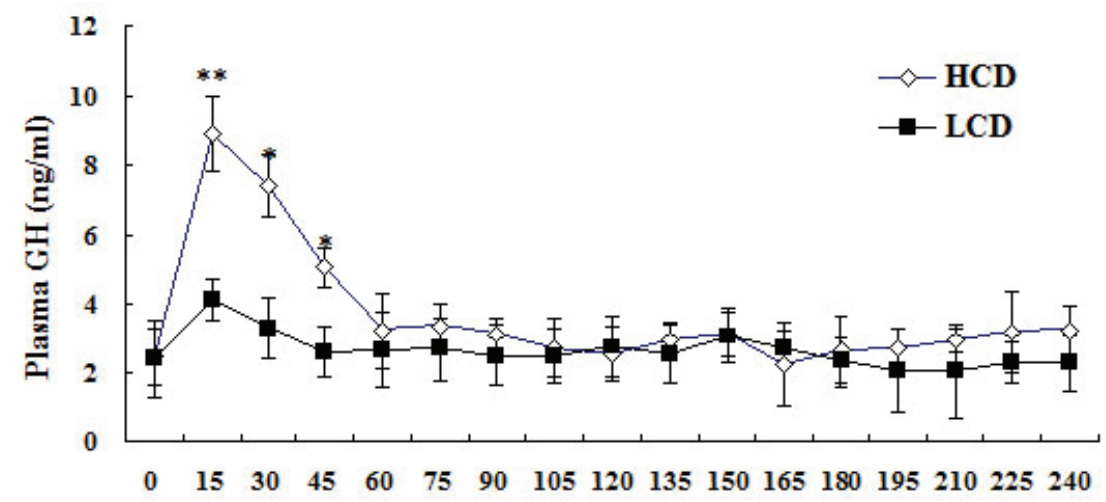

Fig. 2. Plasma $\mathrm{GH}$ concentrations in non-lactating Saanen goats fed a high-concentrate diet (HCD) or lowconcentrate diet (LCD). Each value represents the mean \pm SEM for twelve animals. $\quad * \mathrm{P}<0.05, \quad * * \mathrm{P}<0.01$ compared with the corresponding values for controls

\section{Time in minutes}

A

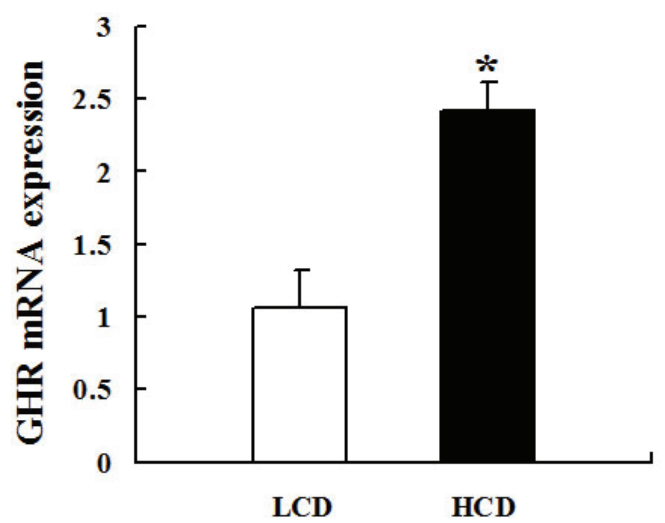

Experiment treatment

B

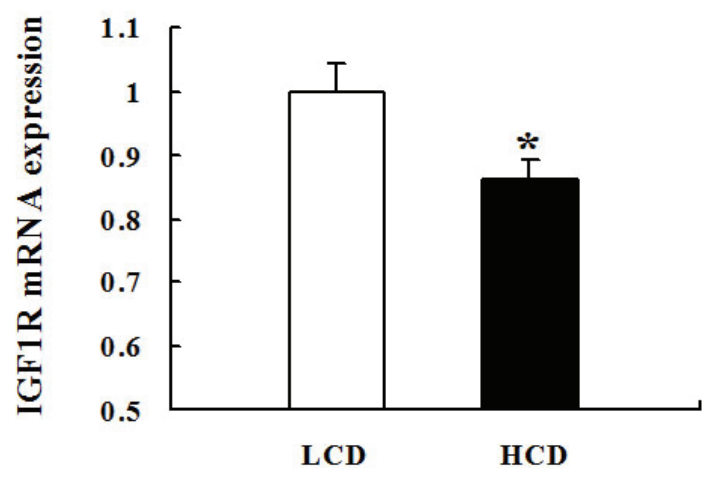

Expe riment tre a tme ent

Fig. 3. Liver GHR and IGF1R mRNA expression in non-lactating Saanen goats fed a high-concentrate diet (HCD) or lowconcentrate diet (LCD). RNA molecules extracted from liver tissue were reverse transcribed to CDNA and analyzed by real-time PCR. Data expressed as arbitrary units relative to $\beta$-actin mRNA. A, GHR mRNA expression; B, IGF1R mRNA expression. Values are mean $\pm S E M, n=12 /$ group. * indicates significant difference between $\mathrm{HCD}$ and $\mathrm{LCD}, \mathrm{P}<0.05$.
The GH/IGF system gene mRNA expressions in liver

The abundances of hepatic GHR mRNA expression was achieved 2.3-fold, higher in the HCD group than that in the LCD group ( $\mathrm{P}<0.05$, Fig. $3 \mathrm{~A})$. In contrast, hepatic IGF1R mRNA expression was markedly reduced in the HCD group in comparison with the LCD group $(\mathrm{P}<0.05$, Fig. 3B).

The relationship with the composition of GH/IGF system in liver, plasma LPL and plasma LPS

Plasma LPL concentration was positively correlated with GHR mRNA expression in the liver $\left(\mathrm{R}^{2}=0.8706, \mathrm{P}=0.036\right.$, Fig. 4A). Conversely, there was a negative correlation between the plasma LPS and GHR mRNA expression in the liver across treatment in $\left(\mathrm{R}^{2}=0.892\right.$, $\mathrm{P}<0.01$, Fig. 4B). There was a negative correlated at $0 \mathrm{~h}\left(\mathrm{R}^{2}=0.4956, \mathrm{P}=0.01\right.$; Fig. $\left.4 \mathrm{C}\right), 2 \mathrm{~h}$ $\left(\mathrm{R}^{2}=0.8517, \mathrm{P}<0.01\right.$, Fig. 4D) and $4 \mathrm{~h} \quad\left(\mathrm{R}^{2}=0.7595\right.$, $\mathrm{P}<0.05$, Fig. 4E).

\section{Discussion}

Although rumen $\mathrm{pH}$ varies considerably within a day, ruminant possess a highly developed system to maintain the $\mathrm{pH}$ within a physiological range. Nonetheless, if acid production from fermentation exceeds the buffering capacity, ruminal $\mathrm{pH}$ compensation fails and the $\mathrm{pH}$ may drop markedly. Previous studies showed that feeding practices in ruminants that use highly fermentable diets, or high concentrate diets, can exhibit decreased ruminal pH (Krause and Oetzel 2006, Stone 2004). Our study showed that the $\mathrm{pH}$ was 
decreased in the HCD group but still exceeded 5.8-6.0 (Table 2), above the pour of SARA (Gozho et al. 2007). Previous studies have reported that intensive feeding of ruminants increased the rate of endotoxin LPS (Emmanuel et al. 2008, Khafipour et al. 2009), but it was clearance or inactivated from the portal circulation by the liver (Andersen et al. 1994b). The results by Harris et al.
(2002) showed that endotoxin was transferred to blood and cleared by liver macrophages or neutralized by lipoproteins. According the LPS result (Fig. 1) showed that LPS was decreased could be attributed to clearance or partially clearance in the liver. However, the exact mechanism about the LPS was clearance should be further investigation in the future.

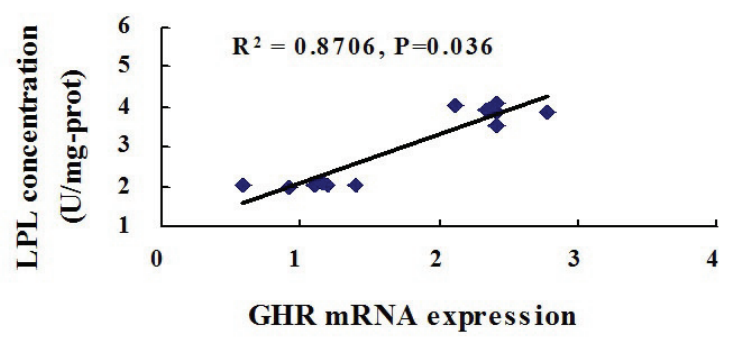

A

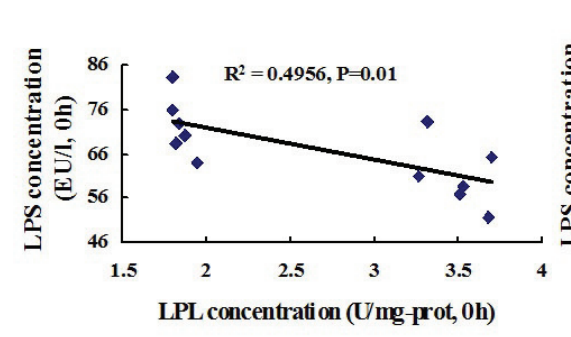

C

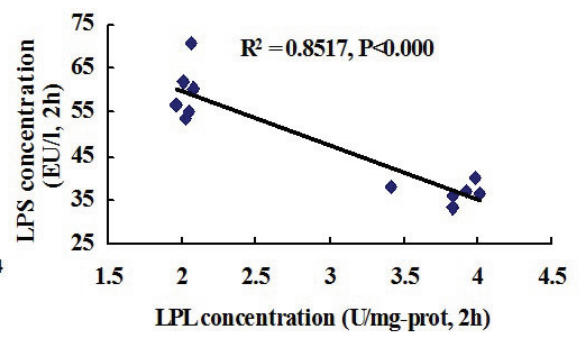

D

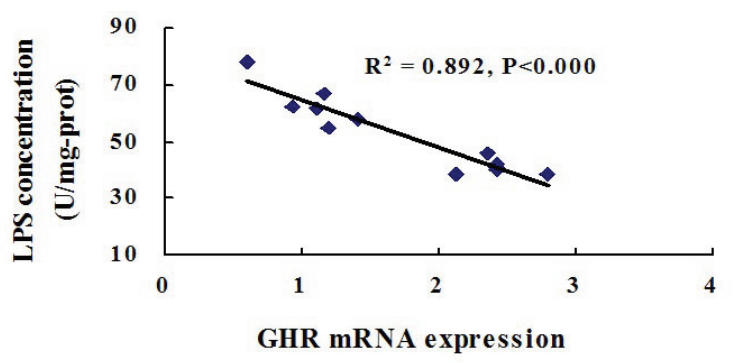

B

Fig. 4. Pearson's correlation between plasma LPL concentration and hepatic GHR mRNA expression or plasma LPS concentration in non-lactating Saanen goats fed high concentrate diet. A, plasma LPL concentration vs. hepatic GHR mRNA expression; B, plasma LPS concentration vs. hepatic GHR mRNA expression; C, plasma LPS concentration vs. plasma LPL concentration (0 h); D, plasma LPS concentration vs. plasma LPL concentration (2 h); E, plasma LPS concentration vs. plasma LPL concentration ( $4 \mathrm{~h}$ ). Values are mean \pm SEM, $n=12 /$ group. The results indicate a significant correlation through the $P$ value at the 0.05 or 0.01 levels.

The IGF1 and IGF1R have a central role in growth regulation and are highly sensitive to nutritional status (Takenaka et al. 1996). Studies have shown that fatty acid supplementation as endogenous ligands for peroxisome proliferator activated receptor (PPAR) also regulate the secretion and transcription of IGF system components (Brown et al. 2003). In this trial, the HCD supplementation decreased IGF1R mRNA expression in the liver of non-lactating Saanen goats (Fig. 3B). Furthermore, the plasma IGF1 concentration decreased in the HCD group (Table 2). The current data confirm the findings of Richards et al. (1991) that nutritional alteration of cycling anestrus animals is associated with decreased circulating concentrations of IGF1.

GH secretory patterns in ruminants are different from that in human. In human the majority of GH is secreted during the night, within a few hours (Casanueva
1992). In contrast, GH secretion appears asynchronous and episodic, and irregular episodic GH pulses occur in ruminant (Hashizume et al. 2005). In the present studies, the high concentrate supplementation significantly stimulated the release of GH after feeding at 15, 30 and 45 min (Fig. 2). GHR has a major somatogenic role could be more responsive to endogenous GH secretion in liver associated nutrition alteration (Katsumata et al. 2000). Additional, Katsumata et al. (2000) explained that upregulation of GHR mRNA expression in response to high concentrate diet intake can be considered as an adaptation the expense of the body growth and development. However, the association between nutrition and stress in endogenous GH secretion is not known in ruminants. Recent in vitro studies showed GH could enhance the transcript levels of GHR mRNA in primary hepatocytes (Fang et al. 2012). This raises the hypothesis that the 
nutritionally induced up-regulation of GHR expression, together with changes in other hormone levels (Fang et al. 2012), may alter metabolism influx in liver to resist the endogenous LPS stress. Especially, LPS could be internalized through the hepatic endosomal pathway via lipoprotein receptors (Harris et al. 2002). In dairy cows, stimulation of GHR abundance by GH to alter the situation of energy deficit leads to reduced expression of the liver GHR gene transcription (Rhoads et al. 2007), and alterations in plasma lipid levels (Birzniece et al. 2009). The regulation of non-lactating goat GHR mRNA by the high-concentrate diet in the present study was accompanied by variations in plasma LPL, especially increased plasma LPL content (Table 2). The LPL serves as a bridge between the cell surface and lipoproteins (Beisiegel et al. 1991, Wong et al. 1994), and bound LPS could rapidly attenuate the hepatocellular response to cytokines in a selective manner, mediated by lipoprotein receptors (Kasravi et al. 2003a). It is interesting that there was a significant negative correlation between plasma LPL and LPS concentration in difference sampling times (Fig. 4C, Fig. 4D and Fig. 4E). According to the previous result, which showed C-terminal domains of LPL have a higher affinity for large triglyceride-rich lipoproteins compared with cholesterol-rich lipoprotein (Lookene et al. 2000). Moreover, increasing the triglyceride-rich lipoproteins could depress the toxicity of LPS, thereby increased plasma LPL concentration has a potential role in depressing the damage from the endogenous LPS in the liver (Kasravi et al. 2003b). As such, we postulate that the changes in hepatic GHR mRNA expression may contribute to the regulation of hepatic LPL activity, which enhances the binding of triglyceride-rich lipoproteins, transferring LPS to high-density lipoprotein and promoting circulating LPS inactivation (Kitchens et al. 2001). Therefore, we can presume the alteration of GH/IGF system and LPL interaction resulting in the endogenous LPS degradation or detoxification in the high-concentrate diet treatment. To our knowledge, this is the first report demonstrating the potential connection between the GH/IGF system in the non-lactating goat and the resistance of the liver to chronic stress. Therefore, further studies are required to confirm this interaction.

Regardless of the mechanism, these data further highlight an important inter-relationship between hepatic GHR and IGF1R mRNA expression with the host response to endogenous LPS stress. These changes were accompanied by variations in the plasma LPL concentration and the GH secretion. Therefore, the GH/IGF system and LPL activity may play an important role in the liver to resist or clear endogenous LPS.

\section{Conflict of Interest}

There is no conflict of interest.

\section{Acknowledgements}

This work was supported by the National 973 Project on milk composition precursors redistribution mechanism and epigenetic mechanism in liver (No.:2011CB100802) and Priority Academic Program Development of Jiangsu Higher Education Institutions. We are also grateful to Dr. G. Lobley for his critical reading of the manuscript.

\section{References}

ANDERSEN PH, BERGELIN B, CHRISTENSEN KA: Effect of feeding regimen on concentration of free endotoxin in ruminal fluid of cattle. J Anim Sci 72: 487-491, 1994a.

ANDERSEN PH, HESSELHOLT M, JARLOV N: Endotoxin and arachidonic acid metabolites in portal, hepatic and arterial blood of cattle with acute ruminal acidosis. Acta Vet Scand 35: 223-234, $1994 \mathrm{~b}$.

BEISIEGEL U, WEBER W, BENGTSSON-OLIVECRONA G: Lipoprotein lipase enhances the binding of chylomicrons to low density lipoprotein receptor-related protein. Proc Natl Acad Sci U S A 88: 8342-8346, 1991.

BIRZNIECE V, SATA A, HO KK: Growth hormone receptor modulators. Rev Endocr Metab Disord 10: 145-156, 2009.

BROWN JM, BOYSEN MS, JENSEN SS, MORRISON RF, STORKSON J, LEA-CURRIE R, PARIZA M, MANDRUP S, MCINTOSH MK: Isomer-specific regulation of metabolism and PPARgamma signaling by CLA in human preadipocytes. J Lipid Res 44: 1287-1300, 2003.

CASANUEVA FF: Physiology of growth hormone secretion and action. Endocrinol Metab Clin North Am 21: 483-517, 1992. 
DAUNCEY MJ, BURTON KA, WHITE P, HARRISON AP, GILMOUR RS, DUCHAMP C, CATTANEO D: Nutritional regulation of growth hormone receptor gene expression. FASEB J 8: 81-88, 1994.

DESJARDINS PR, CONKLIN DS: Microvolume quantitation of nucleic acids. Curr Protoc Mol Biol Appendix 3: 3J, 2011.

EMMANUEL DG, DUNN SM, AMETAJ BN: Feeding high proportions of barley grain stimulates an inflammatory response in dairy cows. J Dairy Sci 91: 606-614, 2008.

FANG XL, SHU G, ZHANG ZQ, WANG SB, ZHU XT, GAO P, XI QY, ZHANG YL, JIANG QY: Roles of $\alpha-$ linolenic acid on IGF-I secretion and GH/IGF system gene expression in porcine primary hepatocytes. Mol Biol Rep 39: 10987-10996, 2012.

GOLDSTEIN S, PHILLIPS LS: Extraction and nutritional/hormonal regulation of tissue insulin-like growth factor 1 activity. J Biol Chem 266: 14725-14731, 1991.

GOZHO GN, KRAUSE DO, PLAIZIER JC: Ruminal lipopolysaccharide concentration and inflammatory response during grain-induced subacute ruminal acidosis in dairy cows. J Dairy Sci 90: 856-866, 2007.

HARRIS HW, BRADY SE, RAPP JH: Hepatic endosomal trafficking of lipoprotein-bound endotoxin in rats. $J$ Surg Res 106: 188-195, 2002.

HASHIZUME T, HORIUCHI M, NONAKA S, KASUYA E, KOJIMA M, HOSODA H, KANGAWA K: Effects of ghrelin on growth hormone secretion in vivo in ruminants. Regul Pept 126: 61-65, 2005.

HUA KM, HODGKINSON SC, BASS JJ: Differential regulation of plasma levels of insulin-like growth factors-I and II by nutrition, age and growth hormone treatment in sheep. J Endocrinol 147: 507-516, 1995.

KASRAVI FB, BRECHT WJ, WEISGRABER KH, HARRIS HW: Induction of cytokine tolerance requires internalization of Chylomicron-Bound LPS into hepatocytes. J Surg Res 115: 303-309, 2003 a.

KASRAVI FB, WELCH WJ, PETERS-LIDEU CA, WEISGRABER KH, HARRIS HW: Induction of cytokine tolerance in rodent hepatocytes by chylomicron-bound LPS is low-density lipoprotein receptor dependent. Shock 19: 157-162, 2003b.

KATSUMATA M, CATTANEO D, WHITE P, BURTON KA, DAUNCEY MJ: Growth hormone receptor gene expression in porcine skeletal and cardiac muscles is selectively regulated by postnatal undernutrition. $J$ Nutr 130: 2482-2488, 2000.

KHAFIPOUR E, KRAUSE DO, PLAIZIER JC: A grain-based subacute ruminal acidosis challenge causes translocation of lipopolysaccharide and triggers inflammation. J Dairy Sci 92: 1060-1070, 2009.

KITCHENS RL, THOMPSON PA, VIRIYAKOSOL S, O'KEEFE GE, MUNFORD RS: Plasma CD14 decreases monocyte responses to LPS by transferring cell-bound LPS to plasma lipoproteins. J Clin Invest 108: 485-493, 2001.

KRAUSE KM, OETZEL GR: Understanding and preventing subacute ruminal acidosis in dairy herds: a review. Anim Feed Sci Tech 126: 215-236, 2006.

LEE WH, GAYLORD TD, BOWSHER RR, HLAING M, MOOREHEAD H, LIECHTY EA: Nutritional regulation of circulating insulin-like growth factors (IGFs) and their binding proteins in the ovine fetus. Endocr J 44: 163 $173,1997$.

LOOKENE A, NIELSEN MS, GLIEMANN J, OLIVECRONA G: Contribution of the carboxy-terminal domain of lipoprotein lipase to interaction with heparin and lipoproteins. Biochem Biophys Res Commun 271: 15-21, 2000.

MCGUIRE MA, VICINI JL, BAUMAN DE, VEENHUIZEN JJ: Insulin-like growth factors and binding proteins in ruminants and their nutritional regulation. J Anim Sci 70: 2901-2910, 1992.

NOSBUSH BB, LINN JG, EISENBEISZ WA, WHEATON JE, WHITE ME: Effect of concentrate source and amount in diets on plasma hormone concentrations of prepubertal heifers. J Dairy Sci 79: 1400-1409, 1996.

O'SULLIVAN DC, SZESTAK TA, PELL JM: Regulation of hepatic insulin-like growth factor I leader exonusage in lambs: effect of immunization against growth hormone-releasing factor and subsequent growth hormone treatment. J Anim Sci 80: 1074-1082, 2002.

PELL JM, SAUNDERS JC, GILMOUR RS: Differential regulation of transcription initiation from insulin-like growth factor-I (IGF-I) leader exons and of tissue IGF-I expression in response to changed growth hormone and nutritional status in sheep. Endocrinology 132: 1797-1807, 1993. 
RENAVILLE R, VAN EENAEME C, BREIER BH, VLEURICK L, BERTOZZI C, GENGLER N, HORNICK JL, PARMENTIER I, ISTASSE L, HAEZEBROECK V, MASSART S, PORTETELLE D: Feed restriction in young bulls alters the onset of puberty in relationship with plasma insulin-like growth factor-I (IGF-I) and IGF-binding proteins. Domest Anim Endocrinol 18: 165-176, 2000.

RHOADS RP, KIM JW, VAN AMBURGH ME, EHRHARDT RA, FRANK SJ, BOISCLAIR YR: Effect of nutrition on the GH responsiveness of liver and adipose tissue in dairy cows. $J$ Endocrinol 195: 49-58, 2007.

RICHARDS MW, WETTEMANN RP, SPICER LJ, MORGAN GL: Nutritional anestrus in beef cows: effects of body condition and ovariectomy on serum luteinizing hormone and insulin-like growth factor-I. Biol Reprod 44: 961-966, 1991.

SHERLOCK M, TOOGOOD AA: Aging and the growth hormone/insulin like growth factor-I axis. Pituitary 10: 189203, 2007.

SMITH JM, VAN AMBURGH ME, DIAZ MC, LUCY MC, BAUMAN DE: Effect of nutrient intake on the development of the somatotropic axis and its responsiveness to GH in Holstein bull calves. J Anim Sci 80: 1528-1537, 2002.

SOHLSTROM A, KATSMAN A, KIND KL, GRANT PA, OWENS PC, ROBINSON JS, OWENS JA: Effects of acute and chronic food restriction on the insulin-like growth factor axis in the guinea pig. J Endocrinol 157: 107-114, 1998.

STEELE MA, ALZAHAL O, HOOK SE, CROOM J, MCBRIDE BW: Ruminal acidosis and the rapid onset of ruminal parakeratosis in a mature dairy cow: a case report. Acta Vet Scand 51: 39, 2009.

STONE WC: Nutritional approaches to minimize subacute ruminal acidosis and laminitis in dairy cattle. J Dairy Sci 87 (Suppl): E13-E26, 2004.

STRAUS DS, TAKEMOTO CD: Effect of fasting on insulin-like growth factor-I (IGF-I) and growth hormone receptor mRNA levels and IGF-I gene transcription in rat liver. Mol Endocrinol 4: 91-100, 1990.

TAKENAKA A, TAKAHASHI S, NOGUCHI T: Effect of protein nutrition on insulin-like growth factor-I (IGF-I) receptor in various tissues of rats. J Nutr Sci Vitaminol (Tokyo) 42: 347-357, 1996.

THORP CL, WYLIE ARG, STEEN RWJ, SHAW C, MCEVOY JD: Effects of incremental changes in forage:concentrate ratio on plasma hormone and metabolite concentrations and products of rumen fermentation in fattening beef steers. $J$ Anim Sci 71: 93-109, 2000.

WALDRON MR, NISHIDA T, NONNECKE BJ, OVERTON TR: Effect of lipopolysaccharide on indices of peripheral and hepatic metabolism in lactating cows. J Dairy Sci 86: 3447-3459, 2003.

WELLER PA, DAUNCEY MJ, BATES PC, BRAMELD JM, BUTTERY PJ, GILMOUR RS: Regulation of porcine insulin-like growth factor I and growth hormone receptor mRNA expression by energy status. Am J Physiol 266: E776-E785, 1994.

WONG H, DAVIS RC, THUREN T, GOERS JW, NIKAZY J, WAITE M, SCHOTZ MC: Lipoprotein lipase domain function. J Biol Chem 269: 10319-10323, 1994. 